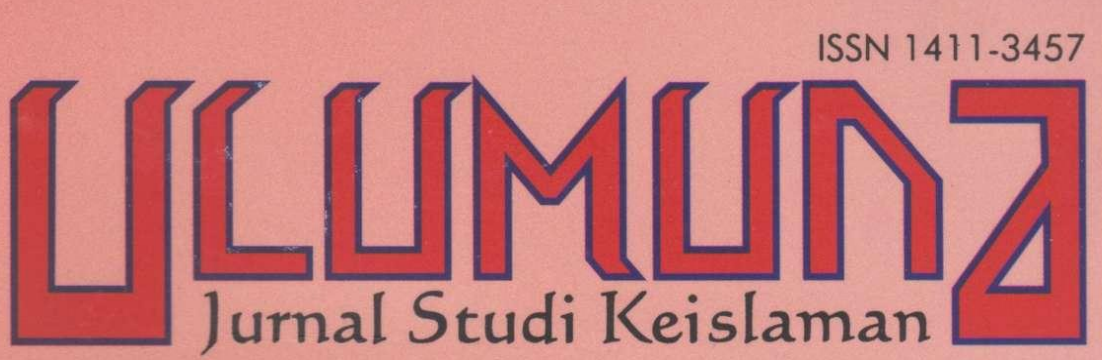
Volume XIV• Nomor 1• Juni 2010

TERAKREDITASI Berdasarkan SK Dirjen Dikti Depdiknas Nomor: 65a/DIKTL/Kep/2008

FILSAFAT ISLAM: ANTARA DUPLIKASI DAN KREASI Abdullah Satar

AL-HIKMAH AL-MUTA'ÂLIYAH: PEMIKIRAN METAFISIKA EKSISTENSIALISTIK MULLA SHADRA Sholihan

HERMENEUTIKA AL-QUR'AN: ANTARA PEMAKNAAN TEKSTUAL DAN KONTEKSTUAL Slamet Mulyono R

MENIMBANG KEMBALI PARADIGMA FILSAFAT ISLAM DALAM BANGUNAN KEILMUAN ISLAM KONTEMPORER Aksin Wijaya

KONTRIBUSI FILSAFAT ILMU DALAM STUDI ILMU AGAMA ISLAM: TELAAH PENDEKATAN FENOMENOLOGI Mulyadi

SIGNIFIKANSI TEORI POPPER, KUHN, DAN LAKATOS TERHADAP PENGEMBANGAN ILMU-ILMU KEISLAMAN Ahmad Choirul Rofiq 
TransLiterasi

Artikel

Abdullah Sattar

Sholihan

Suhermanto Ja'far

Abdul Mukti Ro'uf

Aksin Wijaya

Mulyadi

Slamet Muliono R. Hermeneutika Al-Qur'an:

Antara Pemaknaan Tekstual

dan Kontekstual • 101-120

Menimbang Kembali Paradigma Filsafat

Islam dalam Bangunan Keilmuan Islam

Kontemporer $\bullet 121-144$

Konstribusi Filsafat Ilmu dalam

Studi Ilmu Agama Islam: Telaah

Pendekatan Fenomenologi • 145-176

Ahmad Choirul Rofiq Signifikansi Teori Popper, Kuhn, dan

Lakatos terhadap Pengembangan

Ilmu-Ilmu Keislaman • 177-196

Win Usuluddin

Elusidasi Filosofis Kebhinekaan

Keagamaan: Refleksi atas Pluralisme

Keberagamaan Era Postmodern • 197-226

\section{INDEKS}




\section{PEDOMAN TRANSLITERASI}

\begin{tabular}{|c|c|c|c|c|c|}
\hline Arab & & Latin & Arab & & Latin \\
\hline 1 & $=$ & $\mathrm{a}$ & ف & $=$ & $\mathrm{f}$ \\
\hline ب & $=$ & $\mathrm{b}$ & ق & $=$ & $\mathrm{q}$ \\
\hline$ت$ & $=$ & $\mathrm{t}$ & ك5 & $=$ & $\mathrm{k}$ \\
\hline$\dot{H}$ & $=$ & ts & ل - ل ل & $=$ & 1 \\
\hline 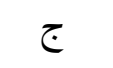 & $=$ & $\mathrm{j}$ & s & $=$ & $\mathrm{m}$ \\
\hline$\tau$ & $=$ & $\underline{\mathrm{h}}$ & ن ن & $=$ & $\mathrm{n}$ \\
\hline$\dot{\tau}$ & $=$ & $\mathrm{kh}$ & و & $=$ & $\mathrm{w}$ \\
\hline د & $=$ & $\mathrm{d}$ & 。 & $=$ & $\mathrm{h}$ \\
\hline$\dot{~}$ & $=$ & $\mathrm{dz}$ & $\Leftrightarrow$ & $=$ & , \\
\hline J & $=$ & $\mathrm{r}$ & ي & $=$ & $\mathrm{y}$ \\
\hline j & $=$ & $\mathrm{z}$ & & & \\
\hline س س & $=$ & $\mathrm{s}$ & & & \\
\hline ش & $=$ & sy & \multirow{2}{*}{\multicolumn{3}{|c|}{$\begin{array}{l}\text { Untuk Madd } \\
\text { dan Diftong }\end{array}$}} \\
\hline ص ص & $=$ & sh & & & \\
\hline ض ض & $=$ & $\mathrm{dl}$ & $i$ & $=$ & â (a panjang) \\
\hline b & $=$ & th & إي & $=$ & $\hat{i}$ (i panjang) \\
\hline ظ & $=$ & $\mathrm{zh}$ & 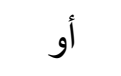 & $=$ & û (u panjang) \\
\hline$\varepsilon$ & $=$ & 6 & او - او & $=$ & aw \\
\hline$\dot{\varepsilon}$ & $=$ & gh & أي & $=$ & ay \\
\hline
\end{tabular}




\title{
PANENTEISME \\ DALAM PEMIKIRAN BARAT DAN ISLAM
}

\section{Suhermanto Ja'far ${ }^{*}$}

\begin{abstract}
Among themes in the studies about God is about problem of existential relationship between God, bumans, and nature. The problem has spawned various perspectives, either normative-theological or metaphysicalontological. Panentheism which is included in the second perspective is a concept that emphasizes the divinity of all in God, not all is God as in the view of pantheism. This paper aims to examine the concept of panentheism by comparing its views developed in the West with those in Islam. West panentheism, as developed by Whitehead, views God as an infinite conceptual reality of absolute possibilities. His existence is not a creation, but He exists with all creations. While in Islamic panentheism, as stated by Iqbal, human pantheistic experience with God does not vanish buman ego, but buman ego even will be more authentic and powerful as it is in the Lord. He rejects pantheism view that all is God.
\end{abstract}

Abstrak: Di antara tema-tema dalam kajian tentang Tuhan adalah tentang bubungan elesistensial antara Tuban, manusia, dan alam. Permasalaban itu telah melabirkan beragam pandangan, baik yang normative-teologis maupun metafisik-ontologis. Panenteisme, termasuk dalam pandangan kedua, adalah sebuah konsep yang menekankan keilahian semua dalam Tuban, tidak semua adalah Tuhan sebagai panteisme Tulisan ini berupaya mengkaji panenteisme dengan membandingkan antara konsep itu pandangan Barat dengan yang ada dalam Islam. Panenteisme Barat, sebagaimana dikembangkan Whitehead, memandang Tuban sebagai realitas konseptual yang tidak terbatas dari kemungkinan-kemungkinan absolut. Keberadaannya bukan sebagai ciptaan, tetapi ia berada bersama semua ciptaan. Sementara dalam pandangan Islam, seperti dikemukakan oleh Iqbal, pengalaman panteistik manusia dengan Tuban tidak membuat lebur ego manusia, justru ego manusia semakin otentik dan kuat karena berada di dalam Tuban; dia menolak pandangan panteisme bahwa semua adalab Tuban.

Keywords: Panenteisme, Metafisika, Ontologis, Teologi Proses, Transenden, Immanen.

*Penulis adalah dosen pada Fakultas Ushuluddin IAIN Sunan Ampel Surabaya.email: herman.goevara@gmail.com. 
PEMBAHASAN tentang Tuhan merupakan fenomena baru di kalangan masyarakat modern yang rasional. Fenomena baru ini, bagi masyarakat modern yang serba mekanis merupakan antitesis dari pengaruh positivisme ${ }^{1}$ yang menolak metafisika, etika bahkan agama, karena ketiga hal tersebut kebenarannya tidak dapat diverifikasi. ${ }^{2}$ Hanya saja, pembahasan tentang Tuhan bagi masyarakat modern berbeda dengan Era Patristik ${ }^{3}$ yang

${ }^{1}$ Suatu kebenaran dapat dianggap benar apabila sesuai dengan hukum positif yang sesuai dengan fakta-fakta atomik yang oleh karenanya dapat dianggap ilmiah. Sedangkan metafisika, etika, maupun agama tidak dapat dibuktikan unsur-unsur atomiknya sehingga tidak dapat dikatakan sebagai kebenaran ilmiah. Gagasan ini dirumuskan oleh filosof Perancis bernama Auguste Comte, yang pertama kali "membuahkan" positivisme melalui fisika sosialnya (yang kemudian disebut sosiologi). Melalui usaha pencarian bentuk inilah Comte kemudian mengajukan serangkaian metode keilmuan bagi ilmu pengetahuan (sosial) dengan upaya penyejajaran ilmu pengetahuan sosial dengan ilmu pengetahuan alam. Pada zamannya, kebenaran ilmu alam merupakan primadona bagi perkembangan keilmuan saat itu. Comte yang kebetulan seorang ilmu sosial, berusaha untuk menyejajarkan kedua jenis ilmu yang dikenal sebagai ilmu alam dan ilmu sosial. Melalui cabang ilmu baru ini, fisika - sosial atau sosiologi, Comte ingin mengajukan hukum yang dapat menerangkan dinamika sosial masyarakat maupun struktur sosial yang telah ada. Untuk lebih jelas, lihat, George Ritzer, Modern sociological Theory (Singapura: The McGraw-Hill Companies Inc., 1996), 14

${ }^{2}$ Verifikasi merupakan kata kunci kaum positivisme dalam memandang sebuah teori yang dianggapnya sebagai yang ilmiah. Verifikasi merupakan metode pengujian sebuah teori, sebagai langkah awal dalam mencari buktibukti yang membenarkan untuk meneguhkan kebenarannya.

3Patristik berasal dari kata patriarchi yang berarti bapak. Dalam sejarah Filsafat, Era Patristik merupakan era dimana Bapak-bapak Gereja (Pastur) menjadi sentral pembahasan Filsafat. Era ini juga diidentikkan dengan Scholastik dimana Bapak-bapak Pastur di Gereja menjadi pengajarnya. Istilah ini mempunyai makna aliran (mazhab) sebagai corak yang khas dari filsafat Abad Pertengahan. Scholastik dapat dirumuskan sebagai sebuah sistem filsafat yang mempunyai corak semata-mata bersifat agama. Disamping itu, juga dianggap sebagai filsafat yang mengabdi pada bidang teologi (ancila teologi) atau filsafat berpadu dengan agama yang berusaha secara rasional memecahkan persoalan-persoalan dengan wahyu. Untuk lebih jelasnya, lihat A. Epping OFM. et.al., Filsafat ENSIE (Bandung: Jemmars,1983), 126-140; bandingkan dengan Frank Thilly, A History of Pbilosophy (New York: Holt, Rinehart and Winston, 1957), 193. 
cenderung teosentris. ${ }^{4}$ Era sekarang, pembahasan tentang Tuhan difokuskan pada pembahasan filosofis dengan titik tekan pada antroposentris, ${ }^{5}$ dimana manusia menjadi tolok ukur dalam hubungannya dengan eksistensi Tuhan. Pada ranah filosofis ini, manusia telah memakai pendekatan epistemologis dalam membahas Tuhan sebagai upaya pembuktian secara ilmiah, rasional, dan logis.

Eksistensi Tuhan merupakan masalah pokok dalam setiap agama dengan pendekatan teologis yang bersumber pada kitab sucinya masing-masing. Di samping itu, juga menjadi pembahasan filsafat dengan perspektif metafisika-ontologis. Pembahasan tentang Tuhan dalam ranah ini menjadi diskursus ${ }^{6}$ menarik karena dalam setiap perkembangan zaman selalu

${ }^{4}$ Teosentris merupakan ciri utama Abad Pertengahan dimana teologi menjadi dasar dari segala-galanya untuk membuktikan keimanan atau keimanan mencari pendasaran filsafat. Dengan kata lain, pembahasan tentang Tuhan menjadi sentral utama abad ini. Pada era ini, filsafat dan pengetahuan menjadi ancila teologi atau hamba teologi. Filsafat dan pengetahuan dipergunakan para teolog untuk membuktikan iman atau iman dipahami secara rasional filosofis, yang dalam istilah Anselmus dikenal dengan intellectum fidei. Suhermanto Ja'far, Konsep Metafisika Moh. Iqbal (Jakarta: Tesis PPS Filsafat UI, 2003), 54-7.

${ }^{5}$ Antroposentris merupakan ciri utama filsafat modern yang berarti manusia menjadi sentral utama pembahasan. Manusia menjadi titik tolak dalam memandang segalanya, termasuk Tuhan. Manusia menjadi subjek sekaligus objek pembahasan filsafat. Melalui antropsentris ini, manusia dengan kebebasan berpikirnyanya mampu menembus batas-batas adi kodtrati melalui penalaran ilmiah sebagai hasil dari revolusi ilmiah sehingga melahirkan peradaban modern. Bertrand Russell, History of Western Philosophy, (London: George Allen \& Unwin, 1974), 157.

${ }^{6}$ Diskursus sering dipadankan dengan istilah wacana. Ada banyak pengertian mengenai wacana, dalam pengertian yang paling luas, wacana berarti sesuatu yang dikatakan atau dikomunikasikan dengan menggunakan tanda-tanda, dan menandai hubungan yang lainnya dengan strukturalisme dan fokus-fokus dominannya pada bahasa. Lihat, Lydia Alix Fillingham, Foucault Untuk Pemula (Jogjakarta: Kanisius, 2001), 100. Namun menurut pengertian Foucault, wacana didefinisikan sebagai bidang dari semua pernyataan (statement), kadangkala sebagai sebuah individualisasi kelompok pernyataan, dan kadangkala sebagai praktek regulatif yang dilihat dari sejumlah pernyataan yang melahirkan kebenaran dan pengetahuan tertentu dan menimbulkan efek kuasa. Michel Foucault, History of Sexuality (New York: Vintage Books, A Division of Random House Inc. 1990), 18. 
muncul diskursus pemikiran tentang Tuhan. Problematika Ketuhanan merupakan problem universal yang selalu ada dalam babakan sejarah manusia sehingga problema ketuhanan tetap dianggap sebagai tema pokok dalam sejarah filsafat. Masalah Tuhan berada pada tingkat pertama spekulasi filosofis.

Sementara itu, dalam ranah teologis, walaupun masalah Tuhan menjadi titik sentral pembahasannya yang didasarkan pada kitab suci, namun tetap saja terbuka kemungkinan bagi adanya interpretasi kreatif terhadap teks-teks suci ajaran Tuhan, termasuk interpretasi kreatif hambanya terhadap eksistensi Tuhan itu sendiri. Ini tampak pada maraknya aliran-aliran atau sekte keagamaan, baik yang berasal dari suatu agama tertentu maupun berakar pada budaya dan pikiran manusia yang bermacam-macam. Ini menujukan bahwa dalam ranah teologis, pemikiran tentang Tuhan selalu berkembang dalam memahami eksistensi Tuhan itu sendiri, baik relasinya dengan manusia maupun alam.

Relasi Tuhan dengan manusia maupun alam merupakan fenomena baru masyarakat modern dalam memahami Tuhan sehingga pendekatan epistemologis menjadi sebuah keharusan. Tuhan dipahami dalam perspektif antroposentris dengan titik tekan pada relasi antara Tuhan dengan manusia dan alam. Relasi antara Tuhan dengan manusia menimbulkan pemikiranpemikiran yang secara filosofis cenderung imanen, pada satu sisi, dan transenden, pada sisi yang lain, bahkan menimbulkan pemikiran yang menganggap bahwa Tuhan itu imanen sekaligus transenden.

Imanensi maupun transendensi merupakan paradigma ontologis-metafisis di kalangan filosof maupun teolog dalam membahas relasi antara manusia dengan Tuhan. Di sinilah terdapat benang merah relasi manusia dan Tuhan dengan pendekatan fenomenologis yang dikenal dengan istilah intensionalitas. ${ }^{7}$ Istilah ini merujuk bahwa manusia mempunyai

${ }^{7}$ Intensionalitas merupakan istilah yang dipopulerkan Husserls sebagai kata kunci dalam fenomenologi. Istilah Intensionalitas berarti, mengarah, mempunyai arah atau tujuan, menuju ke. Konsep ini pertama-tama digunakan oleh Brentano untuk membedakan antara fenomena fisik dengan fenomena psikis. Benda benda fisik tidak terdapat di dalamnya apa yang disebut 
keterarahan dengan yang lain, termasuk Tuhan. Keterarahan manusia kepada Tuhan merupakan suatu keniscayaan. Keterarahan ini semakin jelas dalam pandangan Martin Buber sebagai wujud keterarahan aku dengan Tuhan.

Martin Buber menganalogikan keterarahan manusia pada Tuhan dengan keterarahan pada benda, yang disebut dengan istilah relasi aku-itu dan Aku-engkau. Menurut Martin Buber relasi aku- itu dan Aku-engkau merupakan cara untuk mewujudkan kesadaran Aku. Artinya, bahwa kesadaran Aku bukan tunggal yang hanya ditentukan oleh subjek dirinya, tetapi ditentukan oleh subjek lain (Aku lain) yang dinamakan engkau. Jadi Engkau merupakan suatu dimensi baru meng-ada-kan Aku dalam hubungannya dengan aku lain. Karenanya, hanya dengan pertemuan personal Aku-Engkau, aku mengalami kesadaran dan kehadiran yang nyata. Kehadiran $A k u$ dan Engkau merupakan sisi dari proses menjadi $A D A$. Berangkat dari hal ini, Martin Buber memandang manusia, yaitu Aku selalu dalam relasi dialogis dengan benda-benda (I-it) maupun dengan sesama dan Tuhan (I-Thou). Relasi dialogis ini merupakan suatu keharusan dalam perjumpaan dengan Engkau. Perjumpaan ini menyebabkan Aku menjadi $A d a$ karena Engkau, sebagaimana ucapannya, "Aku membutubkan Engkau untuk menjadi Ada, Aku Ada, karena Aku berkata Engkau. ${ }^{8}$

Pada akhirnya kesadaran yang terdapat pada Aku sebagai inti kepribadian manusia merupakan aktivitas jiwa. Sehingga, kesadaran atau suara hati merupakan aspek etis yang menempatkan roh sebagai bentuk yang paling tinggi dari semua

intensionalitas (bertujuan ke atau mengarah ke). Intensionalitas menunjuk makna aktivitas, "mengarah ke objek atau menuju ke objek". Untuk lebih jelasnya, Khozin Affandi, Fenomenologi: Pemahaman Awal Pikiran-pikiran Edmund Husserl (Surabaya: eLKAF, 2007), 37-40. Adanya relasi subjek dan objek yang berkesadaran ini akhirnya melahirkan istilah cogita cogitata pada fenomenologi Husserl. Ini dibuktikan dengan konsep intensionalitas yang dikandung oleh subjek dengan kesadarannya sehingga dapat mengarah langsung pada objek, yang juga mempunyai kesadaran. Lebih jelasnya, Theodore de Boer, The Development of Husserl's Thought (London: Trans. Mortinus Nijhhoff, 1978), 102.

${ }^{8}$ Martin Buber, I and Thou (Edinburgh, 1970), 54/5. 
itu dan dianggap sebagai jendela jiwa yang terarah pada Allah. ${ }^{9}$ Karena itu, di balik kesadaran manusia terdapat sesuatu yang turut beraktivitas dalam kehidupan sehingga membawa manusia pada yang Mutlak, yaitu Roh. Keterarahan pada yang Mutlak itu merupakan sesuatu yang given bagi manusia karena Allah merupakan ide innate manusia, sebagaimana teori Plato dan Descartes. ${ }^{10}$

Relasi keduanya yang melahirkan konsep imanensi dan transendensi ini dalam perkembangan berikutnya menimbulkan faham-faham ketuhanan yang menjadi perdebatan di antara paham-paham tersebut. Tuhan dianggap sebagai imanen sekaligus transenden bagi penganut teisme; Tuhan dianggap sebagai transenden terhadap alam dan manusia bagi kaum deisme; Tuhan dianggap sebagai yang imanen bagi kaum panteisme. Di samping itu, ada juga yang pesimis bahwa akal manusia bisa menjangkau Tuhan sebagaimana kaum agnostisisme.

Relasi Tuhan dengan manusia dan alam yang dikonsepsikan para teolog yang cenderung spiritualis-monistik beranggapan bahwa peleburan dalam relasi tersebut akan melenyapkan eksistensi manusia dan alam sebagaimana menjadi pegangan kaum panteisme. Sementara itu, dikalangan masyarakat modern yang rasional melalui pendekatan epistemologis beranggapan bahwa peleburan dalam relasi tersebut tidaklah menghilangkan eksistensi manusia dan alam, tetapi justru semakin mengeksiskan manusia. Ini adalah anggapan kaum panenteisme.

Persepsi panenteisme mengenai Tuhan ini menjadi fenomena baru masyarakat modern karena paham ini tidak menafikan kemampuan dan kebebasan manusia. Fenomena ini berangkat dari pemahaman epistemologis filosofis tentang eksistensi Tuhan relevansinya dengan pengetahuan ilmiah sehingga paham ini masih menghargai pengetahuan ilmiah dalam memahami Tuhan. Pengetahuan ilmiah menjadi perangkat metodologis dalam memahami eksistensi Tuhan. Tuhan tidak hanya

${ }^{9}$ C. A. van Peursen, Orientasi di Alam Filsafat, ter. Dick Hartoko (Jakarta: Gramedia,1988), 239-40.

${ }^{10}$ Untuk lebih jelasnya, lihat Sheed's, Dogmatic Theology, vol. I-III (USA: Thomas Nelson Publisher, 1980), 199. 
dipandang dalam perspektif teologis saja. Eksistensi Tuhan menjadi perdebatan yang panjang antara panteisme dengan panenteisme mengenai relasi yang disertai dengan peleburan manusia dengan Tuhan.

\section{Mengurai Arti dan Makna Panenteisme}

Istilah panenteisme telah diperkenalkan pertama kali oleh filosof idealis Jerman Karl Friedrich Christian Krause (17811832). Panenteisme berasal dari kata Yunani " $\pi \tilde{a} \nu$ " (pan) berarti semua, "Év" (en) berarti didalam dan " $\theta \varepsilon o \dot{s}$ " (theos) yang berarti Tuhan. Dengan demikian, berarti Semua berada di dalam Tuhan (all-in-God). ${ }^{11}$ Istilah ini merujuk kepada sebuah sistem kepercayaan yang beranggapan bahwa dunia semesta berada dalam Tuhan. Dengan demikian, panenteisme memposisikan Tuhan sebagai suatu kekuatan yang tetap ada di dalam semua ciptaan, dan teramat kuasa atas semesta. ${ }^{12}$ Bagi Krause (17811832) sebagai seorang Hegelian dan guru Schopenhauer, mempergunakan kata panenteisme untuk mendamaikan konsep teisme dengan panteisme. Istilah panenteisme muncul pertama kali sebagai sistem pemikiran filosofis dan religius pada tahun 1828.

Kaum panenteis menganggap bahwa realitas Tuhan sebagai sesuatu yang transenden sekaligus imanen, Tuhan ada melampaui semua makhluk, namun semua tetap di dalam Tuhan. Gagasan ini telah lama ada berabad-abad sebelumnya di kalangan agama-agama dari berbagai tradisi mistik. Gagasan ini diawali dari Hindu Kuno, yaitu Upanishads 2800 tahun yang lalu, khususnya Brihadâranyaka dan Chândogya Upanishads. Di Barat, gagasan ini dipelopori oleh panenteis Hellenis seperti

${ }^{11}$ Sistem filsafat yang disebut panenteisme oleh Krause pada dasarnya sebagai upaya untuk mendamaikan panteisme dan teisme. Krause menegaskan bahwa Tuhan adalah suatu hakikat yang berisi keseluruhan alam semesta dalam dirinya, namun tidak habis olehnya. Dia menempatkan penekanan khusus pada perkembangan individu sebagai bagian integral dari kehidupan keseluruhan. Untuk lebih jelasnya, John W. Cooper, Panenteisme: The Other God of the Philosophers (Baker Academic: 2006), 18.

12R. Totten, http://www.geocities.com/worldview3/panenteisme.html, diakses pada tanggal 15 Oktober 2009. 
Plotinus (205-70 M.) dan pengikutnya Neo-Platonisme. John Scottus Eriugena (800-877), kepala Palatine Akademi, merupakan panenteis Kristen sekitar abad IX. Para sufi awal di kalangan Muslim seperti Bâyazîd Bisthâmî dan Mansûr al-Hallâj, Ibn 'Arabî dan Jalâl al-Dîn Rûmî termasuk para tokoh yang masuk dalam katagori ini. Begitu pula di kalangan Yahudi muncul di tangan Maimonides dan mistikus Kabbalah seperti Musa dan Cordovero Ishak Luria adalah panenteis.

Sementara itu, pandangan panenteisme di abad XX dan XXI dipengaruhi oleh gagasan teologi proses, yang cenderung menolak transendensi Tuhan, kemahakuasaan, dan kemahatahuan. Para ilmuwan, kosmolog, filosof, dan Teolog di Barat sangat tertarik dengan panenteisme. Mereka mencapai kesepakatan bahwa Tuhan tidak lain alam itu sendiri, setidak-tidaknya ditempatkan sebagai bagian dari itu. Tapi hanya tersedia bagi pengalaman mistik yang terdapat di dalamnya. Mungkin lebih tepat dikatakan bahwa dalam cahaya terbuka "empat sisi" logika dari tradisi spiritual Timur, bahwa Tuhan adalah alam sekaligus melampaui alam, sebagaimana Brockelman menunjukkan bahwa Tuhan bukanlah alam ataupun tidak melampaui alam. ${ }^{13}$

Panenteisme memahami Tuhan dan dunia saling terkait satu sama lain. Tuhan punya relasi timbal balik dengan dunia, dunia berada di dalam Tuhan, dan Tuhan hadir berada di dalam dunia. Gagasan ini menawarkan alternatif baru pemikiran yang semakin populer melalui sisntesis pemikiran teisme tradisional dan panteisme. Panenteisme berusaha untuk menghindari gagasan mengisolasi Tuhan dari dunia sebagamana dipahami teisme tradisional dan gagasan yang meleburkan Tuhan dan dengan dunia sebagaimana panteisme. Sistem pemikiran teistik tradisional menekankan perbedaan antara Tuhan dan dunia secara eksistensial ontologis, sedangkan panenteisme menekankan kehadiran Tuhan aktif di dunia. Sementara itu, Panteisme menekankan kehadiran Tuhan di dunia secara ketat dan utuh, tetapi panenteisme mempertahankan identitas dan makna dari non-ilahi. Antisipasi pemahaman Tuhan yang panenteistik telah terdapat dalam tulisan secara filosofis dan

${ }^{13}$ Http://www.britannica.com/EBchecked/topic/441190/panenteisme diakses pada tanggal 20 Oktober 2009. 
teologis sepanjang sejarah. ${ }^{14}$ Namun, keragaman pemahaman ketuhanan panenteistik telah berkembang di dua abad terakhir, terutama dalam tradisi Kristen menanggapi banyaknya pemikiran-pemikiran ilmiah. ${ }^{15}$

Sebagian besar diskusi kontemporer dan perkembangan panenteisme terjadi dalam konteks diskusi ilmu dan agama. Dalam diskusi yang muncul, Arthur Peacocke dan Paul Davies telah membuat kontribusi penting sebagai ilmuwan yang tertarik pada panenteisme. Peacocke telah mengembangkan pemahaman panenteisme itu diawali pada tahun 1979 dan terus melalui bekerja pada tahun 2001, 2004, dan 2006. Peacocke memulai dengan pergeseran pemahaman ilmiah mengenai dunia dari konsep mekanisme ke dalam pemahaman tentang dunia sebagai kesatuan sistem hirarki dari berbagai tingkatan yang berbeda. Demikian juga halnya juga dengan Davies yang menjelaskan bahwa alam semesta itu kompleks dan teratur. Peacocke mengambarkan pemahaman ilmiah kontemporer tentang alam dan hubungannya dengan Tuhan sebagai relasi eksternal, sebagaimana pemahaman teistik tradisional, di mana Tuhan turut campur tangan dalam dunia alam atau pemahaman deistik yang mana Tuhan memulai alam dunia tetapi tidak terus aktif di dunia. Bagi Peacocke, Tuhan terus mencipta melalui proses dari tujuan alam. Keterlibatan aktif Tuhan bukan merupakan pengaruh eksternal atas peristiwa alam. Bagaimanapun, Tuhan tidak diidentifikasi dengan proses alam, yang merupakan tindakan Tuhan sebagai Pencipta. ${ }^{16}$ Peacocke mengidentifikasi pemahaman relasi Tuhan dengan dunia sebagai panenteisme karena penolakan dari dualisme dan interaksi eksternal oleh Tuhan dalam nikmat Tuhan selalu bekerja dari dalam alam semesta. Pada saat yang sama, Tuhan transenden atas alam

${ }^{14}$ Charles Hartshorne and William L. Reese (ed.), Philosophers Speak of God (Chicago: University of Chicago Press, 1953); John W. Cooper, Panenteism: The Other God of the Philosophers from Plato to the Present (Grand Rapids, MI: Baker Academic, 2006).

15Philip Clayton and Arthur Peacocke (ed.), In Whom We Live and Move and Have Our Being: Panenteistic Reflections on God's Presence in a Scientific World (New York: Grand Rapids, MI: William B. Eerdmans, 2004a), 207-10.

${ }^{16}$ Arthur Peacocke, "Articulating God's Presence in and to the World Unveiled by the Sciences”, dalam In Whom..., 143-4. 
semesta karena Tuhan adalah sangat jauh lebih dari alam semesta. Panenteistik model ini menggabungkan penekanan kuat pada imanensi Tuhan. ${ }^{17}$ Davies juga merujuk kepada pemahaman tentang peran hukum di alam sebagai panenteisme daripada deism karena Tuhan memilih undang-undang yang memberikan peran ko-kreatif pada alam. ${ }^{18}$

Teologi proses menantang pandangan tradisional tentang Tuhan yang selalu diajukan oleh Kekristenan. Keyakinan tradisional tersebut mengakui bahwa Tuhan adalah sempurna dan tidak berubah (statis). Segala bentuk aktivitas manusia tidak dapat memengaruhi atau mengubah Tuhan. Tuhan biasanya dianggap sebagai yang transenden dari dunia. Meskipun demikian, Jurgen Moltmann, seorang teolog Jerman, berpendapat bahwa pandangan tentang Tuhan seperti ini harus ditolak bila ditinjau dengan sorotan inkarnasi. Namun tantangan yang paling radikal datang dari teologi proses ${ }^{19}$ yang didasarkan pada filsafat Alfred North Whitehead (1861-1947). Pada era modern, John Cobb Jr. secara signifikan telah mengembangkan filsafat Whitehead dalam konteks teologi Kristen. Teologi proses juga merupakan suatu kepercayaan panenteistik yang mengakui bahwa segala sesuatu di dalam Tuhan, ketimbang panteistik dengan gagasan bahwa segala sesuatu adalah Tuhan. ${ }^{20}$

Dalam filsafat proses, setiap momen dari eksistensi kita bersifat unik. Ini berarti bahwa dalam setiap momen suatu entitas dihadapkan dengan suatu masa depan potensial di mana dia bebas untuk menerima atau menolaknya. Para filosof proses juga berpendapat bahwa masa depan potensial yang diterima atau ditolak sebagian besar berdasar pada bagaimana kontribusi mereka terhadap kebahagiaan atau kesejahteraan orang lain. Dalam teologi proses, masa depan potensial ini (juga disebut tujuan-tujuan awal [initial aims]) diberikan oleh Tuhan. Lagipula,

${ }^{17}$ Ibid., 147-51.

18 Paul Davies, "Teleology without Teleology: Purpose through Emergent Complexity”, dalam In Whom..., 104.

${ }^{19}$ Jurgen Moltmann, The Crucified God (Evanston, IL: Harper and Row, 1974), 178-200.

${ }^{20}$ John Cobb Jr., A Christian Natural Theology, Based on the Thought of Alfred North Whitehead (Philadelphia: Westminster Press, 1965), 135-55. 
setiap momen yang berlalu tidak hilang, melainkan terserap ke dalam Tuhan dan ditambahkan ke dalam pengalaman Tuhan (God's experience). Jadi dalam setiap momen, Tuhan terus-menerus belajar setahap lebih tinggi tentang diri kita. Dia belajar sebagai Tuhan yang hadir dalam tiap momen eksistensi kita. ${ }^{21}$

Meskipun teisme klasik berpendapat bahwa Tuhan dalam beberapa cara berjarak atau transenden dengan dunia, namun dalam teologi proses Tuhan tidak terpisah dari proses-proses dunia (imanen). Sebagai Tuhan yang juga suatu entitas, yang sama dengan orang-orang seperti kita, Tuhan memiliki kutub fisik (masa lalu) dan kutub mental (masa depan potensial). Dalam kutub mental, Tuhan mempertimbangkan semua skenario yang mungkin terjadi dan menghadirkannya di hadapan kita dalam masing-masing momen melalui entitas-entitas yang memikat terhadap potensi mereka. Kunci keyakinan dalam teologi proses adalah bahwa Tuhan tidak pernah memaksa suatu entitas menuju suatu masa depan potensial. Tuhan juga dibatasi oleh kebebasan dari suatu entitas yang lain untuk menolak kesan potensial Tuhan. Dalam teologi proses kita dilihat sebagai rekan sekerja (co-worker) dengan Tuhan, bukan sebagai subjek-subjek ilahi yang dibatasi hanya untuk melakukan kehendak Tuhan. ${ }^{22}$

Dalam teologi proses, Tuhan juga menjadi penderita yang mengerti. Tidak seperti teisme klasik, bagi para teolog proses Tuhan tidak mahakuasa (omnipotent) dan tidak tahu tentang masa depan. Tuhan hanya mengenal masa depan sebagai suatu aktualitas potensial, bukan realitas aktual! Ini berarti, Tuhan dalam beberapa hal terbatas. Tuhan tidak dapat memaksakan kehendak ilahi kepada manusia dan mengawasi konsekuensikonsekuensi dari setiap momen untuk melihat bagaimana masa depan berlangsung. Itu juga berarti bahwa dalam setiap tindakan membawa dunia ke dalam eksistensi Tuhan membutuhkan kesempatan. Seperti yang dicatat John Cobb Jr, "Tuhan mengalami resiko dan bertualang dalam eksperimen kosmik, sambil menyisakan sumber kegelisahan dalam dunia" [God

${ }^{21}$ Ford, Lewis (ed.), Two Process Philosophers: Hartshorne's Encounter with Whitehead (Tuhanassee, FL: American Academy of Religion, 1973).

${ }^{22}$ Dorothy Emmett, "Whitehead and Alexander", Process Studies, vol. III (1993), 137-48. 
undergoes risk and adventure in cosmic experiment, while remaining the source of unrest in the world]. Kemahatahuan (omniscience) berarti Tuhan mengetahui segala sesuatu yang telah terjadi hingga kini, tetapi tidak segala sesuatu yang akan terjadi. Kini meskipun sikap optimistik ini dalam perkembangannya dapat ditemukan masalah: "karena Tuhan tidak mahakuasa, maka tidak ada garansi bahwa kehendak baik akan berpuncak pada kemenangan alam semesta". Kenyataannya, kehendak baik hanya unggul sejauh kita merespons kehendak ilahi untuk "mengasihi" di antara seluruh entitas. Namun sebagai Tuhan yang tidak pernah memaksa, tetapi mendorong untuk mengikuti kehendak ilahi, terdapat kemungkinan riil bahwa manusia bisa memilih untuk tidak mengikuti Tuhan itu sendiri. ${ }^{23}$

Secara jelas, teologi proses menggeser sikap mempersalahkan apa yang salah dalam dunia yang menjauh dari Tuhan, dan masuk ke dalam kemanusiaan. Jika Tuhan memiliki potensi untuk ditolak, maka kejahatan adalah sautu hasil-bentukan dari suatu proses bergerak menjauh dari Tuhan. Pilihan-pilihan buruk yang tak terelakkan akan dibuat oleh berbagai entitas yang memiliki kebebasan untuk menolak atau menerima kesan Tuhan (keterpikatan ilahi). Ini berarti Tuhan tidak dapat membiarkan kejahatan karena Tuhan tidak siap menghadapinya sejak awal. Tuduhan bahwa Tuhan bisa menjadi jahat atau impoten dengan membiarkan kejahatan, tidak berlaku di sini karena masalah ini berada di luar jangkauan tangan Tuhan. Terlebih, kuasa dan aktivitas Tuhan dibatasi karena kita punya pilihan-pilihan riil untuk dibuat. Kini sementara orang akan merasa tidak senang dengan pandangan tentang Tuhan seperti ini. Karena pandangan tersebut tidak memberikan kepastian bahwa dalam beberapa hal di masa depan semua akan beres di alam semesta. Itu juga mencuatkan beberapa hal untuk dipertanyakan mengenai keyakinan para teolog proses tentang hakikat Tuhan. ${ }^{24}$

Teologi proses mempunyai beberapa unsur atraktif untuk menjelaskan masalah tersebut. Misalnya, keyakinan bahwa

${ }^{23}$ Philip Clayton, "God and World", dalam The Cambridge Companion to Postmodern Theology, ed. Kevin J. Vanhoozer (Cambridge: Cambridge University Press, 2003), 203-18.

${ }^{24}$ Ibid. 
hubungan antara Tuhan dan kemanusiaan adalah kooperasi mutual, membimbing pada hasil positif agama dalam masyarakat sejauh sebagai orang percaya yang mengikuti contoh ilahi. Teologi proses mendorong orang percaya untuk mendengarkan dan memahami ketimbang melawan orang lain dengan kebenaran versi mereka, melalui kontribusi signifikan yang jauh dalam wilayah teodisi).

Kosmologi "Dentuman Besar" (Big Bang) secara jelas memperkuat ajaran utama dalam filsafat proses bahwa dunia selalu berada dalam dinamika naik-turun (fluktuasi). Alam semesta kita bukanlah wilayah yang statis. Hukum alam yang telah diobservasi di masa lampau, kini dipersoalkan dalam sorotan berbagai penemuan baru saintifik. Pandangan kita tentang alam semesta sebagai subjek wilayah mekanistik untuk hukum-hukum yang pasti (fixed laws) juga telah direvisi dalam sorotan teori kuantum.

Ada pemahaman baru tentang dunia ini, bahwa teologi proses telah memfasilitasi hubungan baru antara agama dan sains. Yakni, jika alam semesta pada hakikatnya adalah terbuka, maka Tuhan dapat bertindak dalam dunia. Lebih lanjut, jika, sebagaimana postulat teolog proses, Tuhan berkarya dalam dan dengan dunia dan prosesnya, ketimbang menentang dan mengeluarkannya, maka Tuhan berkarya dalam suatu konteks hukum alam. Dengan demikian, tidak ada peristiwa apapun di ala mini yang berada di luar karya Tuhan, karena apa yang dipandang sebagai hokum alam pada dasarnya juga karya Tuhan. Jadi menurut para teolog proses, Tuhan tidak melanggar hukumhukum alam, sebagaimana Tuhan tidak akan mengganggu hakikat kita (didasarkan sekitar paham kehendak bebas). Ini berarti bahwa Tuhan dapat bertindak dalam dunia dengan cara tersendiri ketika individu secara partikular terbuka untuk kehendak ilahi. Jika memang demikian halnya, maka muncul pertanyaan: "apakah Tuhan telah melakukannya di masa lampau atau akan melakukannya di masa depan?" Terbuka juga pertanyaan: "apakah Tuhan telah menunjukkan mukjizat di masa lalu atau dapat melakukannya di masa depan?"25

${ }^{25}$ Carl Gillett, "Physicalism and Panenteism: Good News and Bad News", Faith and Philosophy, 20 (2003), 323. 


\section{Pemikiran Whitehead tentang Panenteisme}

Whitehead dikenal sebagai tokoh terkemuka dalam aliran "Filsafat Proses" atau seperti yang disebutnya sendiri sebagai "Filsafat Organisme". Buah pemikirannya banyak berpengaruh di dunia, terutama di Amerika Serikat dan di beberapa negara di Eropa. Ia lahir dalam keluarga Kristen Anglikan di Ramsgate, Kent, Inggris 15 Februari 1861 dan meninggal di Harvard pada tahun 1947, setelah sepuluh tahun pensiun sebagai profesor filsafat di Universitas Harvard.

Sepanjang karirnya, Whitehead banyak menulis buku baik di bidang filsafat maupun di bidang lainnya seperti matematika dan teologi. Antara lain buku-buku tersebut adalah: "Principia Mathematica" (1919), "Enquiry Concerning the Principles of Natural" (1919), "The Concept of Nature" (1920), "The Principle of Relativity" (1922), "Science and Modern Word" (1925), "Religion in Making" (1927), "Process and Reality" (1929), "The Aim of Education", "Modes of Thought" (1938) dan berapa buku lain dan artikelartikelnya tentang filsafat dan ilmu pengetahuan.

Salah satu dari banyak tema yang di kemukakan Whitehead dalam filsafat organismenya adalah pemikiran-pemikiran tentang Tuhan. Pandangan-pandangannya tentang hal ini dapat dilihat pada bukunya "Process and Reality", "Religion in Making", dan "Science and Modern Word". Pemikiran-pemikirannya tentang Tuhan inilah yang akan dibahas dalam tulisan ini.

Secara organis, filsafat Whitehead dibangun dengan beberapa konsep dasar yang di sebutnya sebagai "kategori eksistensi" (category of existence), ${ }^{26}$ terdiri dari: satuan-satuan aktual (actual entity), kreativitas (creativity), objek-objek abadi (eternal world), prehensi (prehension), dan kebersamaan (nexus). Konsep-konsep dasar ini merupakan gagasan asli yang di ciptakan sendiri untuk menerangkan filsafatnya.

Sebagai konsep dasar, menurut Whitehead, Tuhan adalah ujud asali dan prinsip dasariah dari kreativitas, sekaligus merupakan prinsip dasar konkresi atau proses munculnya satu satuan aktual dari banyak satuan aktual lain yang menjadi data warisan masa lalu. Dalam hal ini, Tuhan merupakan perwujudan

${ }^{26}$ Ibid., 206. 
perdana dari kreatuifitas dan sekaligus sebagai pembatas dan pemberi arah berlangsungnya kreatuifitas tersebut.

Sebagai perwujudan perdana dari kreativitas dan sekaligus pemberi arah baginya, Tuhan tidak dapat dipisahkan dengan kategori eksistensi yang lain yang disebut objek-objek abadi (eternal object). Lebih jauh Whitehead menjelaskan bahwa sebagai “pembatas asali' (ultimate limitation) dari satuan-satuan aktual, eksistensi Tuhan adalah irrasional kekal. ${ }^{27}$ Pokok soal dalam hal ini adalah Tuhan tidak ditentukan secara metafisis meskipun ditentukan secara kategoris. Dengan demikian, Tuhan bukanlah merupakan "kategori eksistensi" yang konkret, tetapi Dia menjadi dasar dari semua yang konkret. Tuhan tidak bisa dipahami dengan pikiran, sebab secara hakiki, Ia adalah dasar dari rasionalitas.

\section{Bipolaritas Tuhan}

Menurut Whitehead, terdapat dua pola (bipolar) dalam kenyataan Tuhan. Kedua pola tersebut adalah pola aktual dan pola potensial. Pola aktual adalah alam semesta yang secara kodrati berubah secara total, dan pola potensial adalah dunia abadi (eternal) yang tidak mengalami perubahan. Dengan kata lain Whitehead berpenadapat bahwa terdapat dua aspek dalam "kategori eksistensi" Tuhan, yaitu aspek primordial dan aspek konsekuen, yang akan diuraikan berikut ini.

\section{Aspek Primordial}

Dalam aspek primordialnya, Tuhan adalah "kategori eksistensi" yang pada mulanya memikirkan segala kemungkinan yang dapat diwujudkan dalam seluruh alam semesta. Dalam hal ini, Tuhan merupakan realitas konseptual yang tidak terbatas dari kemungkinan-kemungkinan absolut. Keberadaannya bukan sebagai ciptaan, tetapi ia berada bersama semua ciptaan. Lebih jauh dijelaskan oleh Whitehead bahwa dalam aspek primordial ini, Tuhan memberi wujud konseptual kepada semua "objek abadi" dengan memberi segala macam bentuk kemungkinan yang bisa berwujud untuk semua satual aktual. Oleh karena itu,

27 Alfred North Whitehead, Science \&o The Modern World (Middlesex: Penguin Books Limited, 1938), 207-8. 
Tuhan dalam aspeknya yang primordial ini menjadi sumber segala cita-cita atau tujuan akhir dari semua proses konkresi untuk perwujudan diri satu-satuan aktual. Sebagai "kategori eksistensi" yang primordial, Tuhan sangat jauh dari "realitas unggul" (eminent reality) yang di dalam abstraksi ini Ia merupakan "realitas aktual yang kurang sempurna". ${ }^{28}$

\section{Aspek Konsekuen (Aspek Akhiri)}

Aspek Tuhan yang konsekuen menurut Whitehead, adalah suatau kesadaran yang merupakan realisasi dunia aktual dalam hakekat kesatuan dan melalui transformasi kebijaksanannya. Jika aspek primordial adalah konseptual, maka aspek konsekuen ini adalah susunan perasaan fisis Tuhan pada aspek primordialnya itu. ${ }^{29}$ Susunan itu terdiri dari berbagai unsur dan realisasi diri secara individu. Dalam hal ini, keberamaan dipandang sama dengan kesatuan: seperti "satu-banyak" (much one) fakta perantara yang berkembang tanpa melebihi dirinya.

Relasi Tuhan dengan dunia Menurut Whitehead bahwa Tuhan dan dunia, secara aktual tidak dapat dipisahkan. Dunia adalah hakekat kemuliaan Tuhan yang terjadi dari banyak fakta dasariah dan turunan pengalaman atau peristiwa aktual. Dengan kata lain, dunia adalah urutan atomistik dari kejadian-kejadian. Ia berada dalam semua proses mengalirnya benda-benda dan merupakan generalisasi awal yang tidak jelas, tidak disistematisasikan, hampir tidak dapat dianalisa, dan dihasilkan oleh intuisi manusia. Sebab itu, perubahan terus-menerus dari benda-benda adalah suatu generalisasi dasariah yang harus disusun di dalam sistem filsafat kita. ${ }^{30}$

Dalam kepaduan dunia dengan Tuhan, menurut Whitehead, mereka berada dalam posisi yang melengkapi. Dalam hal ini, Tuhan merupakan dasar yang tidak terbatas dari semua yang bersifat mental dan kesatuan dari visi mencari keragaman fisis. Sedangkan dunia adalah berbagai batasan-batasan dan aktualitas-

28 Alfred North Whitehead, "Process and Reality", dalam Philosophers Speak of God, ed. Charles Hartshorne dan William L. Reese (Chicago: Midway Reprint-University of Chicago, 1976), 278-9.

${ }^{29}$ Ibid., 521-2.

30Ibid., 280. 
aktualitas yang mencari kesempurnaan suatu kesatuan. Baik dunia maupun Tuhan, berada dalam lingkup metafisika dasariah dan pengembangan ciptaan ke arah pembaruan. Kedua hal ini merupakan instrumen kebaruan bagi yang lain.

Tuhan digambarkan Whitehead sebagai suatu daya dinamis yang secara imanen berfungsi dalam pergulatan hidup manusia di dunia, bukannya sebagai individu yang serba transenden, sempurna, tinggi, jauh dan mencukupi dirinya sendiri. Tuhan juga disebutnya sebagai penyair dunia, yang dengan kesabarannya memimpin dunia dengan visi kebenaran, keindahan, dan kebaikan" (the poet of the world, with terder patience leading it by vision of truth, beauty, and goodness). ${ }^{31}$ Hartshorne, salah seorang murid Whitehead yang mendalami teologi proses, menggolongkan pandangan Whitehead sebagai panenteisme modern (dunia di dalam Tuhan). Secara literal, panenteisme (pan-en-theism) diartikan sebagai: semua-di dalam-Tuhan.

Menurut Norman L. Geisler dan William Watkins, panenteisme memiliki nama lain seperti : teologi proses (jika melihat Tuhan sebagai ada yang berubah); teisme bipolar atau dipolar (jika percaya bahwa Tuhan memiliki pola ganda); teologi organisme (jika memandang semua yang terjadi sebagai organisme besar/gigantik); dan teisme Neo-klasik (karena percaya bahwa Tuhan adalah terbatas dan temporal, berlawanan dengan teisme klasik). ${ }^{32}$

\section{Pemikiran Iqbal tentang Panenteisme}

Perjalanan hidup Muhammad Iqbal (selanjutnya di tulis Iqbal) begitu kompleks dan panjang dari tanah kelahirannya sampai pengembaraan intelektualnya di Barat, sehingga beliau benar-benar merupakan seorang pemikir besar di Barat maupun di Timur. Bahkan beliau merupakan sosok pemikir yang besar di dua peradaban dan kebudayaan yaitu Barat dan Timur (Islam). Sehingga tidak salah kalau Saiyidain menganggap Iqbal

${ }^{31}$ Ibid, 282.

${ }^{32}$ Norman L. Geisler dan William Watkins, Perspectives Understanding and Evaluating Today's Views (California: Here's Life Publisher, Inc., 1984), 100. 
merupakan seorang tokoh legendaris yang agung di antara para pujangga di negerinya, ${ }^{33}$ bahkan di dunia.

Pemikiran ontologi Iqbal lebih mengarah pada eksistensi Realitas Absolut, sebagai realitas yang sebenarnya dalam hubungannya dengan manusia dan alam. Karena itu, Realitas Ultim, Realitas Diri, Wujud Mutlak atau Ego Mutlak hanya dapat dicapai dengan intuisi. Untuk sampai mengetahui dan memahami Wujud Mutlak, Iqbal bertitik tolak dari intuisi tentang wujud ego manusia yang bergerak pada Realitas Wujud Ego Mutlak. Hanya intuisi, kata Iqbal, yang dapat mengungkap Realitas Mutlak atau Wujud Super Ego yang sebenarnya. Hal ini karena kodrat Realitas yang sesungguhnya adalah spiritual. Realitas Mutlak sebagai Ego oleh al-Qur'an disebut dengan nama Allah menurut Iqbal. ${ }^{34}$

Tuhan menurut Iqbal adalah hakikat keseluruhan yang bersifat spiritual. Dengan kata lain, Tuhan bukanlah ego, melainkan Ego Mutlak. Tuhan bersifat mutlak, karena meliputi segalanya dan tidak ada sesuatupun di luar Dia. Pada akhir-akhir menjelang kematiannya, Iqbal semakin menampakkan pemikirannya yang orisinal mengenai Tuhan sebagai hakikat keseluruhan dari segala kreativitas, karena Tuhan sendiri selalu kreatif memberikan ilham tentang filsafat perubahan, tindakan, aksi yang lebih dikenal dengan istilah Islam adalah amal. Disinilah letak sintesa filosofi Iqbal dari Barat maupun Timur (Islam) dengan pemikirannya yang orisinil. Sekalipun sesungguhnya, konsep tentang gerak hubungan dengan Tuhan telah dimulai dari Aristoteles.

Iqbal memandang secara seimbang bahwa pengalaman panteistik manusia dengan Tuhan tidak membuat lebur ego manusia, justru ego manusia semakin otentik. Filsafat ketuhanan Iqbal disini justru lebih memperkuat eksistensi ego manusia sehingga pemikirannya lebih bersifat panenteisme. Panenteisme merupakan konsep ketuhanan yang menitik beratkan pada semua

${ }^{33}$ K. G. Saiyidin, Percikan Filsafat Iqbal Mengenai Pendidikan, ter. M. I. Soelaeman (Bandung: Diponegoro, 1981), 13.

${ }^{34} \mathrm{M}$. Iqbal, The Recontruction of Religious Thought in Islam (New Delhi: Kitab Bhavan, 1981), 38-9. 
di dalam Tuban, bukan semua adalab Tuhan sebagaimana panteisme. ${ }^{35}$

Bagi Iqbal, alam semesta bukan sebagai suatu produk yang sudah selesai dan lengkap, tetapi sedang berada dalam tahaptahap penyempurnaan. Penciptaan alam bukanlah penciptaan yang final. Menurut Iqbal, penciptaan adalah sebuah proses yang berkelanjutan, sedang manusia berada di dalam turut ambil bagian dalam proses tersebut sehingga akan selalu berproses dengan menciptakan situasi-situasi dan produk-produk baru. Alam semesta sebagai kumpulan ego-ego menurut Iqbal merupakan wadah keinginan-keinginan untuk untuk selalu melakukan perubahan-perubahan yang baru dalam kehidupan ini. Alam semesta sesungguhnya selalu berada dalam becoming (menjadi). Ini disebabkan adanya aktivitas ego-ego yang berkelanjutan dalam alam sehingga kehidupan dalam alam selalu merupakan suatu perjalanan tanpa akhir. Alam seperti yang kita lihat, menurut Iqbal, bukan benda materi murni yang menempati ruang hampa. Alam semesta merupakan struktur-struktur peristiwa, model perilaku yang sistematis dan bersifat organis. Alam merupakan perilaku Diri Tuhan (Ego Absolut) seperti halnya karakter untuk ego manusia. Disinilah Iqbal membandingkan watak ego manusia dengan watak alam. Keteraturan alam ini merupakan perilaku Allah, demikianlah gambaran al-Qur'an, sebagaimana dikutip Iqbal. ${ }^{36}$

Menurut Iqbal dengan merujuk pada al-Qur'an bahwa: pertama, alam semesta diciptakan bersifat teleologis atau bukan suatu ciptaan sekedar main-main; kedua, Alam semesta bukan bersifat tertutup atau penciptaan yang sudah selesai dan alam semesta merupakan ciptaan yang tetap, tetapi masih bisa berubah. Ketiga, Alam semesta tercipta dengan teratur, tertib dengan perjalanan waktu yang teratur dan tepat yang dicontohkan oleh al-Qur'an melalui pergantian siang dan malam sebagai salah satu tanda (ayat) kebesaran Tuhan. Keempat, Alam semesta dengan ruang dan waktu yang terhampar luas ini diciptakan untuk kepentingan manusia dalam rangka beribadah

${ }^{35}$ Charles Hartshorne dan William Reese, Philosophers Speak of God (Chicago-London: The University of Chicago Press, 1976), 294-7.

36Iqbal, Reconstruction ..., 56-7. 
dan nerenungkan ayat-ayat-Nya (tanda-tanda kebesaran-Nya). Semua ini menurut Iqbal sebagai bukti bahwa alam semesta merupakan fakta yang aktual. ${ }^{37}$

Tuhan menurut Iqbal mencipta secara tak terbatas dan kreatif terus menerus dimana posisi manusia bukanlah boneka pasif bagi kehendak Tuhan melainkan co creator yang aktif berpartisipasi dalam penciptaan kreatif Tuhan. ${ }^{38}$ Proses penciptaan oleh Tuhan menurut Iqbal bukan seperti proses penciptaan sepatu yang kreativitasnya berada pada level paling rendah. Proses penciptaan oleh Tuhan dapat diasosiasikan dengan creative genius seorang komposer atau penyair. Manusia sebagai co creator pilihan Tuhan berbagi creative genius Tuhan untuk direalisasikan dalam dunia atau sederhananya: manusia diberkahi Tuhan kebebasan untuk dapat berpartisipasi aktif dalam proses kreatif penciptaan-Nya. Setiap proses berkarya yang dilakukan manusia pada dasarnya merupakan bentuk partisipasi manusia dalam karya-Nya. Berangkat dari pemahaman Iqbal ini, maka Iqbal merupakan pengikut dari panenteisme atau teologi proses. Karena itu, relevan sekali Hartshorne dan William Reese memasukkan Iqbal sebagai panenteis muslim. 39

\section{Catatan Akhir}

Menurut Hartshorne, panenteisme dapat dipahami melalui analogi: sama seperti satu organisme ada, baik sebagai kumpulan semiautonomous, setiap sel-sel individu dan mandiri sebagai individu yang lebih menonjol daripada kumpulan sel. Tuhan dapat dilihat sebagai kumpulan semua unsur bagian dari realitas dan sebagai sesuatu yang lebih dari alam semesta itu sendiri. Walaupun kita, bersama dengan sisa dari keberadaan, namun dapat dipikirkan sebagai bagian dari tubub Tuhan. Kesadaran atau pikiran Tuhan yang lebih luas melampaui tubuh dan menyebabkan Tuhan menjadi lebih daripada sekedar kumpulan bagian..$^{40}$

\section{${ }^{37}$ Ibid., 10-1.}

${ }^{38}$ Lihat Majid Fakhry, A History of Islamic Philosophy (New York: Columbia University Press, 1983), 351.

${ }^{39}$ Hartshorne dan Reese, Philosophers ..., 295.

40Ibid., 312. 
Gagasan Panenteistik tentang kebebasan adalah cara yang unik dalam membahas masalah kejahatan. Sementara theisme cenderung atribut jahat hanya pada dunia dan panteisme cenderung mengidentifikasi kejahatan di dunia sebagai kejahatan Tuhan, panenteisme mengambil posisi jalan tengah, sedangkan yang mengatakan bahwa kejahatan yang terjadi melalui kebebasan di dunia ini tidak berpengaruh pada esensi Tuhan, Tuhan masih dapat dirasakan melalui pengalaman dalam. Ini posisi jalan tengah mungkin merupakan kasus panenteisme dari jenis pertama, namun karena ini sebagian panteistik, condong ke arah gagasan yang menyatakan bahwa ketika manusia berbuat kebaikan ataupun kejahatan di dunia, maka ia melakukannya dengan Allah.

Meskipun filosofi panentheism jembatan dari kesenjangan paradigma antara theisme dan panteisme, yang banyak dipahami oleh sejumlah besar utama kelompok agama dan teologi, juga bukan dari sekte kecil atau pandangan filosofi pribadi. Elemen panenteisme muncul di hampir setiap sistem keagamaan yang diberikan setiap kali digambarkan, sebagai baik seluruhnya, tetapi juga sangat Kuasa terhadap eksistensi dunia. Transendensi dan imanensi Tuhan terlihat hampir pada setiap agama. Para teolog dengan lebih tegas lagi menyebutnya dengan istilah Tuhan dua sisi. Sementara teolog reformer Belanda, yaitu Hendrikus Berkhof 41 menyebutnya dengan bipolar theisme dalam proses teologi. ${ }^{42}$ Dengan demikian panenteisme, terutama dari jenis yang kedua, mendapatkan momentum pengembangannya pada para teolog kontemporer. Konsep itu juga dapat menjadi jembatan di antara agama dan filsafat, khususnya untuk mendapatkan landasan yang logis bagi kepercayaan agama mengenai sifat-sifat Tuhan. Wa al-Lâh a lam bi al-shawâb.

${ }^{41}$ Hendrikus Berkhof, Christian Faith: An Introduction to the Study of the Faith (Grand Rapids, MI: William B. Eerdmans Publishing Co., 1986), 114.

${ }^{42}$ John B. Cobb, Jr. and David Ray Griffin. Process Theology: An Introductory Exposition (Westminster John Knox Press, 1977), 47. 


\section{Daftar Pustaka}

A. Epping OFM. et.all., Filsafat ENSIE (Bandung: Jemmars, 1983).

Alfred North Whitehead, "Process and Reality", dalam Philosophers Speak of God, ed. Charles Hartshorne dan William L. Reese (Chicago: Midway Reprint-University of Chicago, 1976). , Science \& The Modern World (Middlesex: Penguin Books Limited, 1938).

Arthur Peacocke, "Articulating God's Presence in and to the World Unveiled by the Sciences", dalam In Whom We Live and Move and Have Our Being, ed. P. Clayton and A. Peacocke (Grand Rapids, MI: William B. Eerdmans, 2004).

Bertrand Russell, History of Western Philosophy (London: George Allen \& Unwin, 1974).

C.A. van Peursen, Orientasi di Alam Filsafat, ter. Dick Hartoko (Jakarta: Gramedia, 1988).

Carl Gillett, "Physicalism and Panenteisme: Good News and Bad News", Faith and Philosophy, edisi 20 (2003).

Charles Hartshorne and William L. Reese (ed.), Philosophers Speak of God (Chicago: University of Chicago Press, 1953).

Charles Hartshorne dan William Reese, Philosophers Speak of God (Chicago-London: The University of Chicago Press, 1976).

Dorothy Emmett, "Whitehead and Alexander", Process Studies, vol. III (1993).

Frank Thilly, A History of Philosophy (New York: Holt, Rinehart and Winston, 1957).

George Ritzer, Modern Sociological Theory (Singapura: The McGraw-Hill Companies Inc., 1996).

Hendrikus Berkhof, Christian Faith: An Introduction to the Study of the Faith (Grand Rapids, MI: William B. Eerdmans Publishing Co., 1986).

Http://www.britannica.com/EBchecked/topic/441190/panent eisme, diakses pada tanggal 20 Oktober 2009.

John B. Cobb Jr. and David Ray Griffin, Process Theology: An Introductory Exposition (Westminster John Knox Press, 1977). 
, A Christian Natural Theology, Based on the Thought of Alfred North Whitehead (Philadelphia: Westminster Press, 1965).

John W. Cooper, Panenteism The Other God of the Philosophers: From Plato to the Present (Grand Rapids, MI: Baker Academic, 2006).

Academic, 2006).

, Panenteism: The Other God of the Philosophers (Baker

Jurgen Moltmann, The Crucified God (Evanston, IL: Harper and Row, 1974).

K.G. Saiyidin, Percikan Filsafat Iqbal Mengenai Pendidikan, ter. M. I. Soelaeman (Bandung: Diponegoro, 1981).

Khozin Affandi, Fenomenologi:Pemahaman Awal Pikiranpikiran Edmund Husserl (Surabaya: eLKAF, 2007).

Lewis Ford (ed.), Two Process Philosophers: Hartshorne's Encounter with Whitehead (Tuhanassee, FL: American Academy of Religion, 1973).

Lydia Alix Fillingham, Foucault Untuk Pemula (Jogjakarta: Kanisius, 2001).

M. Iqbal, The Recontruction of Religious Thought in Islam (New Delhi: Kitab Bhavan, 1981).

Majid Fakhry, A History of Islamic Philosophy (New York: Columbia University Press, 1983).

Martin Buber, I and Thou (Edinburgh, 1970).

Michel Foucault, History of Sexuality (New York: Vintage Books, A Division of Random House Inc. 1990).

Norman L. Geisler dan William Watkins, Perspectives Understanding and Evaluating Today's Views (California: Here's Life Publisher, Inc., 1984).

Paul Davies, "Teleology without Teleology: Purpose through Emergent Complexity", dalam In Whom We Live and Move and Have Our Being, ed. P. Clayton and A. Peacocke (Grand Rapids, MI: William B. Eerdmans, 2004).

Philip Clayton and Arthur Peacocke (ed.), 2004a, In Whom We Live and Move and Have Our Being: Panenteistic Reflections on God's Presence in a Scientific World (New York: Grand Rapids, MI: William B. Eerdmans, 2004a). 
Philip Clayton, "God and World", dalam The Cambridge Companion to Postmodern Theology, ed. Kevin J. Vanhoozer (Cambridge: Cambridge University Press, 2003).

R.Totten,http://www.geocities.com/worldview 3/panenteisme. html. Diakses pada tanggal 15 Oktober 2009.

Sheed's, Dogmatic Theology, vol. I-III (USA: Thomas Nelson Publisher, 1980).

Suhermanto Ja'far, Konsep Metafisika Moh. Iqbal (Jakarta: Tesis PPS Filsafat UI, 2003).

Theodore de Boer, The Development of Husserl's Thought (London: Trans. Mortinus Nijhhoff, 1978). 